Science, Technology and Society in Europe

April 2013
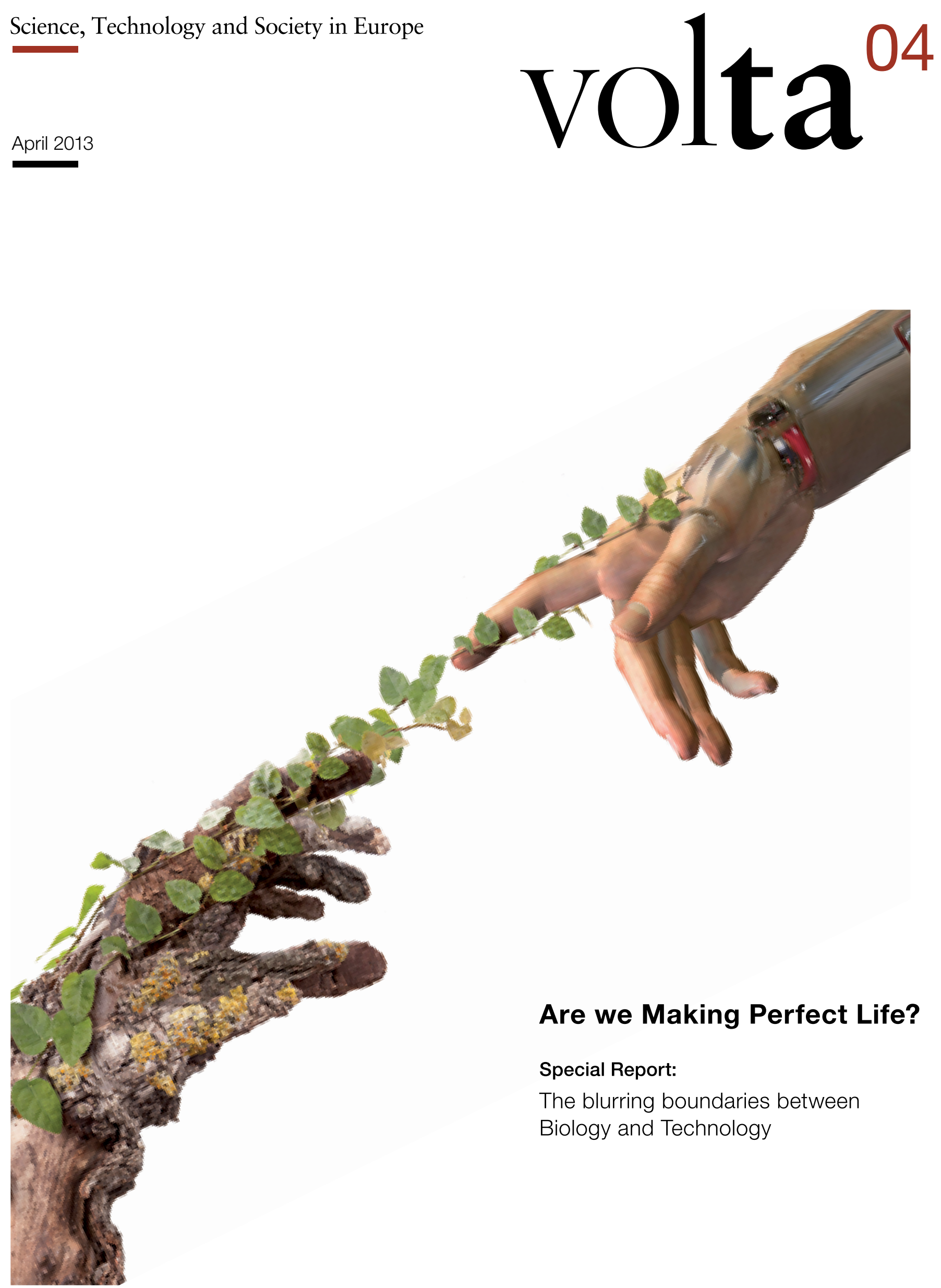
$\therefore 04$

.

$=06$

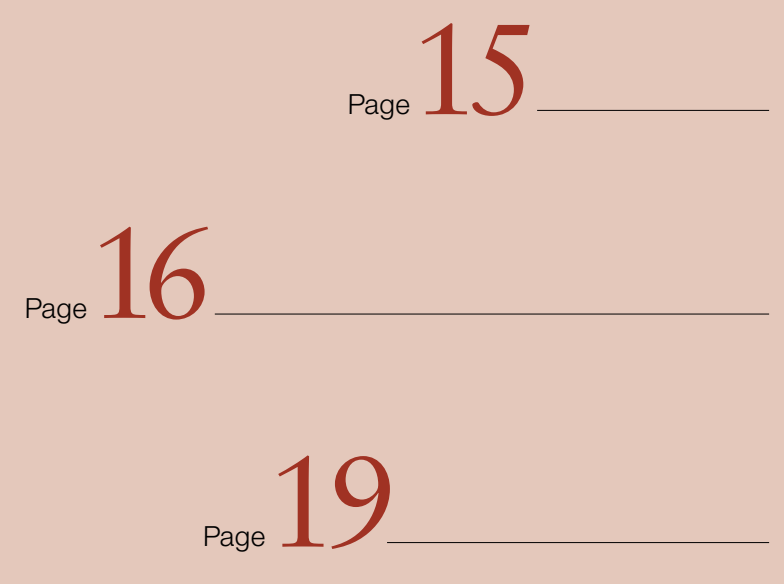

$\operatorname{mox} 20$

21

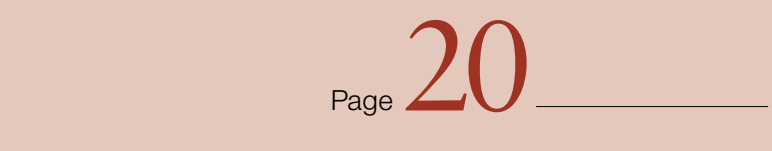

D fabric | Highlight

Zsuzsanna Szentirmai-Joly

on her moving fashions

Bioengineering | Special Report

Are we making perfect life?

Future Panels | The Method

Policy-making

and visionary thinking

Freedom of Information | Interview António Barreto numbers are not enough

The CIVISTI Project | Masterclass Citizens are consultants on emerging technologies

Great transitions | Feature

The Prague report

pase 24

Clinical Trials | Speakers' Corner Safer and more transparent? 
Advisory Board

Sergio Bellucci - Ta Swiss - Swiss Centre for Technology Assessment - Switzerland

Iva Vancurova - Technology Centre ASCR Czech Republic

Lars Klüver - Danish Board of Technology Foundation - Denmark

Leonhard Hennen - Institute for Technology Assessment and Systems Analysis (ITAS) -

Germany

Editorial Team

Antoinette Thijssen (editor-in-chief), Rathenau Instituut - The Netherlands

Pascal Messer, Janneke Visser (managing editors), Rathenau Instituut

Belén López, Catalan Foundation for Research and Innovation (FCRI) - Catalonia

\section{To merge or not to merge}

Living things are quite different from dead things. Or so we feel. Although my I3-year old daughter thinks she cannot live without her mobile phone, some of us still believe that things that breathe are perhaps more sacred than things that do not breathe.

We are starting to understand complex organisms in terms of their components and processes. But, we take comfort in acknowledging that within even the humblest bacterium there is an indefinable 'something'.

So it might be difficult to imagine that the wet stuff of animate beings and the dead stuff of man-made mechanical devices are rapidly merging.

Yet, that is exactly what is happening. Biology is becoming technology, and technology is becoming biology. 'Making Perfect Life', an ambitious, multi-disciplinary European technology assessment study, shows how these two radical bio engineering megatrends will dramatically impact our lives and society. Think of Google glasses, digitally 'improving' our reality, or personalised medicine based on genome sequencing, or brain implants that can improve or cure us. And think of robot soldiers that decide for themselves when to kill. Do we want to be told to take our medicine by a robot nanny?

Politicians and policymakers: read the Special Report and get your yellow marker pens out. Regulatory issues in abundance. We need to take a reality check. Are we prepared for just how far and fast bioengineering is progressing? Are you up to speed with the technological breakthroughs associated with NBIC convergence?

With bioengineering becoming ever more ambitious and potent, discussions and political decisions are needed before 'damage control' is all that is left as a policy option. Technology shapes our society. But society also needs to be comfortable with it. That is what Technology Assessment addresses.

What exactly do we want to merge? And what do we want to remain pure?

Pascal Messer, on behalf of the Editorial Team p.messer@rathenau.nl
Katalin Fodor, Hungarian Academy of Sciences - Hungary

Marianne Barland, Norwegian Board of Technology - Norway

Ingrid Geesink, Rathenau Instituut

Contributors

Sarah Adamopoulos, Marianne Barland, Gaston Dorren, Philip Droge, Adele Flakke Johannessen, Katalin Fodor.

Text Editor

Ann Maher

Concept

Pascal Messer

Design \& Distribution Co-ordination

Belén López, Iván Barreda.

Design

Petit Comitè (Catalonia)

Photography

Antònio Barreto, Birgitte Blandhoel, Milan

Blstak, Horváth Dániel, Gettyimages,

iStockphoto, Francois Joly, Miklos Koren, Petit

Comitè, Elisabeth Steiner.

Cover

Petit Comitè (Catalonia)

Cover idea

pd productions (The Netherlands)

Printing

Industrias Gráficas Galileo, S.A. (Catalonia)

Website

http://volta.pacitaproject.eu/

Legal deposit

B-40368-20II

Volta was made possible by
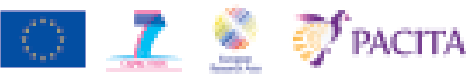

Volta is an initiative of fifteen technology assessment organisations that work together in the European Pacita project - a four-year EU financed project aimed at increasing the capacity and enhancing the institutional foundation for knowledge-based policy-making on issues involving science, technology and innovation. www.pacitaproject.eu

Danish Board of Technology Foundation (Denmark); Karlsruhe Institute of Technology (Germany); The Rathenau Institute (Netherlands); Norwegian Board of Technology (Norway); The Institute of Technology Assessment (Austria); Applied Research and Communications Fund (Bulgaria); Institute of Technology of Biology and Chemistry (Portugal); Institute Society and Technology (Flanders, Belgium); Catalan Foundation for Research and Innovation (Catalonia, Spain); Swiss Centre for Technology Assessment (Switzerland); Knowledge Economy Forum (Lithuania); Technology Centre ASCR (Czech Republic); University of Liège, SPIRAL Research Centre (Wallonia, Belgium); University College Cork (Ireland); Hungarian Academy of Sciences (Hungary). 


\section{Expanding the TA Landscape}

What challenges are faced by countries attempting to introduce Technology Assessment?

Networking for the future

Bureaucratic and hierarchical R\&D systems, dependence on EU funding and lack of awareness and public debate are just a few of the obstacles facing TA advocates, according to a new PACITA report Expanding the TA-landscape: Country Studies. It examines in depth the barriers and opportunities for introducing TA in Bulgaria, Czech Republic, Hungary, Ireland, Lithuania, Portugal and Wallonia (Belgium).

Each country report draws research from national documents, interviews with actors from politics, science, industry and civil society as well as from two national workshops where national stakeholders and European TA experts discussed possibilities for national TA landscapes. Case studies further illustrate possible TA-topics and related political processes, for example, a parliamentary committee on shale gas exploration in Bulgaria, the public debate on nuclear waste management in the Czech Republic and the closure of the Irish council for bioethics. Comparative findings from the country studies highlight the historical context of TA as well as the political contexts. The activities documented in the country studies not only contribute to an analysis of the national political structures but also the potential of a network that could lead to the establishment of a national TA community and the TA capacities for policy advice in the future.

Although a range of issues including non-transparent decision-making and lack of trust in democratic structures can be seen in each of the countries studied, according to the report, "All this results in an explicit demand for knowledge-based policy-making. In this context, the (not very well known) concept of TA is welcome".

Expanding the TA-Landscape: Country Studies (December 2012) Editors: Leonhard Hennen and Linda Nierling

For more information, see the PACITA website www.pacita.eu

\section{Technological diversification a key to economic stability}

Are economies eternally destined to face the unexpected and unpredictable?

In a recent study, Miklós Koren and Silvana Tenreyro investigate how technologically more competitive countries manage to maintain a steady economic growth in times of crisis while economies of less developed countries are hit hard: "The model's key idea

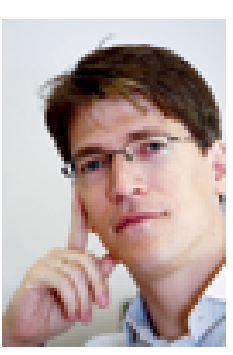
is that firms using a large variety of inputs can mitigate the impact of shocks affecting the productivity of individual varieties." The study, published in February 2013 in the American Economic Review, provides important reference points for innovation and industrial policy makers.

\section{Technological Diversification} Koren Miklós and Silvana Tenreyro, American Economic Review (2013), 103(1):378-414

\section{Coming up}

\section{ESOF 2014}

Call for proposals

The theme for Europe's largest general science meeting is 'Science Building Bridges'. Scientific session proposals are welcomed based around eight themes: The Healthy Society; A revolution of the Mind; Global Resource Management; Learning in the 21st Century; Green Economy; Material and Virtual World; Urbanization, Design and Liveability; Science, Democracy \& Citizenship. The first deadline for proposals is 9 May 2013.

www.esof2014.org

Euroscience Open Forum (ESOF)

2014, Copenhagen, Denmark, 21-26 June 2014
Inspired by Science

Hailed by the New York Times as 'a new cultural institution', The World Science Festival is a production of not-for-profit organization, the Science Festival Foundation. Its mission is to cultivate a general public informed and inspired by science. Special events, at locations around New York, include Science-on-Site in Brooklyn Bridge Park; Innovation Square at Polytechnic Institute of NYU, and Cool Scientists (with amazing jobs) at Hunter College. www.worldsciencefestival.com World Science Festival 2013, New York, USA, 29 May -2 June 2013

\section{EU seeking input}

The purpose of this conference is to provide input to the European Commission on the future research needs in Horizon 2020. Abstracts are invited on three major themes: Climate action: mitigation and adaptation; Resource efficiency: natural resources, ecosystems, raw materials; Green economy: ecoinnovation. The deadline for the first call for abstracts is 1st May 2013. www.dce-conference.au.dk

Science for the Environment 2013, Århus, Denmark, 3-4 October 2013 


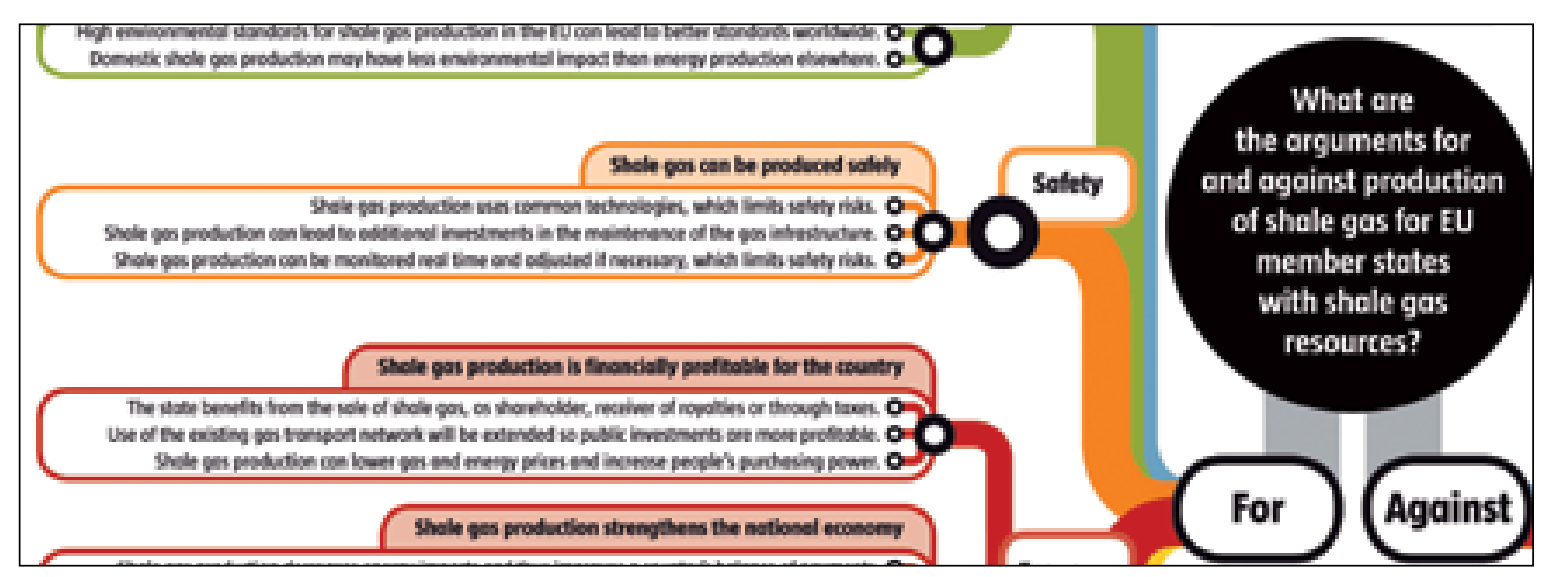

\section{Visual thinking}

Still shilly-shallying over shale? Dutch institute TNO has teamed up with the Argumentation Factory to address one of Europe's hottest environmental issues.

Pros and Cons of shale gas

Visualising arguments helps people assemble their throughts and get to grip with complex problems according to The Argumentation Factory, based in Amsterdam. Their Argument Maps, constructed for government agencies, NGOs and commercial organizations, are designed to enable people to make better decisions and share and communicate information.

Dutch research organisation TNO, in association with The Argumentation Factory, have launched the European Shale Gas Argument Map detailing the pros and cons of the production of shale gas for EU member states with shale gas resources. Their map is designed to provide the foundation for an open discussion and help the user make a balaced assessment.

"Currently there is a public debate on shale gas in different EU Member States and an independent overview of the arguments is essential to enable the parties to come to a consensus," says Lambert van Nistelrooij, member of the European Parliament.

"The European Shale Gas Argument Map is perfectly suited to this end since it has been developed by the independent organisation TNO together with the Argumentation Factory and international stakeholders from the public and private sector, government, NGOs and research organisations."

René Peters, Director of Gas technology at TNO, emphasises that at first the risks have to be studied as well as alternative methods of production of shale gas in order to keep costs and risks down. "There is a debate on the pros and cons of shale gas. That is all right. But TNO thinks that the decision on whether or not to proceed to acquiring shale gas should be a well-informed one." TNO commissioned the Argumentation Factory to accompany the research process that took place with various international stakeholders from public and private sectors including government, NGOs and research institutions in order to identify the advantages/disadvantages indicators.

The process is not yet closed since it was determined there was still a lot to know. "If it appears that certain aspects are marked insufficiently on the map," continues Peters, "the arguments map will be adjusted accordingly. Our goal is to have all arguments neutral on a list without indicating how important or weighty an argument is."

www.tno.nl

www.argumentenfabriek.nl
Argument map summarizes all arguments used in the shale gas debate. Shown here are
the safety ones used by those in favour of shale gas. Visit http://volta.pacitaproject.eu/ visual-thinking/ for a complete vision of the map. 


\section{The blurring boundaries} between biology and technology Making Perfect Life?

Biology and technology are merging in many more ways than ever imagined. An ambitious technology assessment study, Making Perfect Life, has delved deeply into the changes this might entail. How can policy makers ensure these are mostly for the good?
Whatever lives is fundamentally different from dead matter, or so we feel. As 2ist-century citizens of industrial societies, many of us still believe that things that breathe are more sacred than things that do not. We may know that organisms are complex systems that can be understood in terms of their components and processes. But deep down, many of us feel that within the humblest bacterium there is an indefinable something that has so far escaped our analysis. How can the wet stuff of animate beings and the dead stuff of human-made contraptions merge seamlessly into one?

Yet that is just what is happening in labs around the world. Scientists and engineers are increasingly blurring the boundaries between organic creatures and mechanical creations. Four technosciences are involved, each of them offering their own perspective and technological contribution. It's known as the NBIC convergence - Nanotechnology, Biotechnology, Information Technology and Cognitive science. To span the organic-mechanical gap, bridges are being built from both sides. 


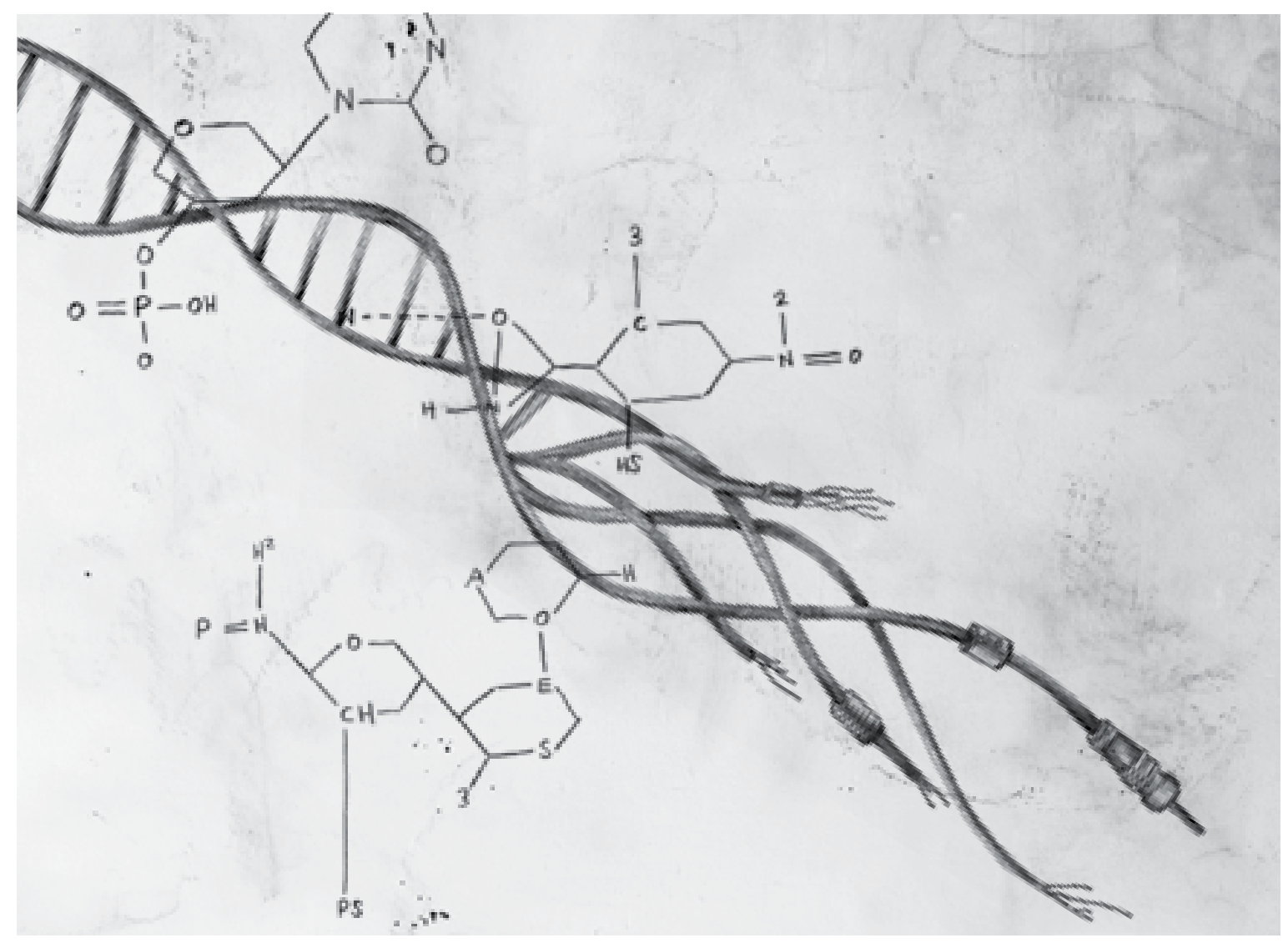

"The life sciences are approaching their subject in a more and more technological way," says Rinie van Est (Rathenau Institute, The Hague), project leader of Making Perfect Life. "Biologists are no longer content to study or even manipulate organisms, but are bent on building new ones from scratch. In terms of their ambitions, that's nothing less than a revolution. Equally novel is how the physical sciences are nowadays drawing inspiration from the functioning of living things and trying to imitate them. The Blue Brain Project, for instance, aims to replicate the entire human brain in a computer system, the hope being that with a full understanding of its functioning, we will be able to build more powerful and efficient computers."

Informed by this observation, the project team chose 'biology becoming technology, technology becoming biology' as their guiding concept.

"These are two megatrends that will have a huge impact on the future of our society", says van Est. "And in a way, the two are really one, because they reinforce or even help to create each other. It reminds you of the famous Escher picture of the two hands. Together, the trends represent a new engineering approach to life."

\section{Controversial science}

Along with nuclear power, biotechnology has been one of the most consistently controversial fields of scientific endeavour in recent times. Even today, techniques such as genetic engineering and cloning leave many people uncomfortable and are subject to restrictive regulation, especially in Europe. Will the new megatrends of biology becoming technology and vice versa lead to a similar sense of unease and to new bans and guidelines? "There's certainly reason to discuss the foreseeable consequences of the innovations very carefully," according to van Est. "That's exactly the debate we are hoping to have initiated with Making Perfect Life. And it's not just that, say, medicine will be able to cure more diseases - that would be relatively straightforward. Several of the new technologies are already being eyed up by other industries. We call that 'a change in social practices', and though there's nothing at all wrong with it per se, it does raise a whole range of new regulatory issues."

So much for the general concepts - let's get down to the nitty gritty. The researchers have distinguished four main areas where the megatrends of bioengineering are playing out. They've labelled them intelligent artefacts, living artefacts, interventions in the body and interventions in the brain.

\section{Making Perfect Life}

Making Perfect Life is a study commissioned and funded by the European Parliament, as a project of the Parliament's Science and Technology Options Assessment (STOA) Panel, under the responsibility of Malcolm Harbour and Vittorio Prodi, MEPs. STOA contributes to the debate on strategic scientific and technological issues of political relevance and the policy options for tackling them through projects of a medium to long-term, interdisciplinary character, as well as information and dialogue activities, whose outcomes are relevant to the European Parliament in its role as legislator. 
Intelligent artefacts are machines that have certain lifelike qualities without being alive in any biological sense. They have chips, not genes; they have metal and plastic components, not tissues. This is worth keeping in mind, because otherwise claims and fears can easily be overblown. These artefacts are equipped with sensors to register a variety of signals, especially those emitted by human bodies. Our good old organic senses already have synthetic counterparts. Several sorts of sensors have been around for a while, but they still illustrate the trend of technology-becomingbiology. Human signals registered include sound, as in speech, grunts and squeaks, and mechanical signals, commonly known as movement and body language. Other examples include chemical, electrical and thermal signals.

From these observations, computer software determines what we are 'doing' and how we are 'feeling'. An appropriate response is calculated, which could consist of words, actions or a rudimentary display of 'emotions'. If all goes well, the human partner will indeed perceive these as adequate. (Sometimes, however, not all goes well: with more than one person in a room, systems can get individuals mixed up.) When these digital skills, such as they are, are uploaded to an ambulant device, you're looking at a smart robot. When the skills are integrated into our living environment, the result is known as ambient intelligence. In both cases, we're dealing with artefacts that are more interactive and closer to human than we've been used to so far.

With machines that respond adequately and in real time to our individual physical and psychological state, we already seem to be fulfilling the prediction that animate beings and inanimate contraptions will merge seamlessly. But an even smoother human-machine interface has hit the labs: neurophysiological computing. Here, just one thing is measured: patterns of brain activity. From these, emotions can be inferred. This is the technology steering thought-controlled wheelchairs, and which has also captured the imagination of computer games manufacturers and users. These new, intimate links between humans

\section{Biology is becoming technology}

'Biology becoming technology' implies and promises new types of interventions which further enhance the manipulability of living organisms, including the human body and brain. It is illustrated by 'top-down' synthetic biology, molecular medicine, regenerative medicine, forward engineering of the brain and persuasive technology. The physical sciences (nanotechnology and information technology) are enabling progress in the life sciences, like biotechnology and cognitive sciences, creating a new set of engineering ambitions with regards to biological and cognitive processes, including human enhancement, so that in the future genes, cells, organs, and brains, can be bio-engineered in much the same way as nonliving systems, like bridges and electronic circuits. and machines are expected to find applications in three fields.

\section{Sensitive interaction}

The first of these are computers skilled in sensitive interaction, enabling them to take the place of human communication partners. They can function as extremely patient teachers, constantly eager computer-game adversaries or highly accurate doctors or nurses. Don't be surprised when you see such systems appear and spread in e-learning, gaming and health care some time soon, because they've already reached the clinical testing stage.

But will we be comfortable with these ambiguous 'beings' around us, that are lifeless and lifelike at the same time? "It can be very hard sometimes to see the difference between a machine and a living being," says Brigitte Krenn, an Austrian researcher of artificial intelligence. She gives a relatively lowtech example: "I know of one case where an old lady in a home for the elderly was confused by an emergency call coming from the intercom system she thought a voice was talking to her through the television." But it's not just the elderly. Who can truthfully claim never to have been wrong-footed by a synthetic telephone voice, mistaking the speaker for a flesh-and-blood person? Machines are becoming more human. Krenn suggests that what is going on inside a machine should be visible on the outside - a hardware equivalent of the 'what you see is what you get' concept in software.

Philosophers are not afraid to raise questions that are simultaneously naive and profound. So, "Do we need all these new applications?", wonders Jutta Weber (Technical University, Braunschweig), "especially when not everybody knows how to handle them?" She believes we need to give people a better technical education in using computers and applications first. Instead of just inventing things (and the list of innovations that never caught on is a long one), engineers should ask people what they need in their daily lives. This is not to suggest that engineers are attempting to push any old innovation down society's throat, but that user needs and preferences should be taken into account at an early stage.

\section{Technology is becoming biology}

The 'technology becoming biology' trend embodies a (future) increase in bio-, cogno-, and socioinspired lifelike artefacts, which will be applied in our bodies and brains, be intimately integrated into our social lives, or used in technical devices and manufacturing processes. These (anticipated) new types of interventions and artefacts present a new technological wave that is driven by NBIC convergence. It is illustrated by 'bottom-up' synthetic biology, the shift from repair to regenerative medicine, reverse engineering of the brain and the engineering of living artefacts. This, after future development relies heavily on so-called biomimicry or biomimetics: learning from the achievements of nature (though there's room for improvement). 
The second application of machines with human-

like interactive skills is the benevolent personal supervisor. Computers that monitor how we feel (fit or tired, alert or drowsy, amused or bored) and that are capable of intervening when we fall into an undesirable state. When our bodily signals cross some predetermined threshold the computer will take action. Systems that alarm car drivers that are dozing off are already on the market, and are bound to spread to other types of travel. Bored with a computer game? The manufacturer will want to measure when that happens too.

\section{Ambient intelligence}

The third application occurs when a computer is integrated into an everyday residential environment. Here, the user interface becomes as good as imperceptible. In ambient intelligent applications, sharp sensors are built into the living space - artificial eyes, ears and noses. Early efforts have been concentrated at environments for the elderly and infirm, to enable them to lead more independent lives. Ambient intelligence is likely to figure in other areas including 'intelligent' homes, health care and support for the disabled, as well as industry and business. Brigitte Krenn's misgivings about machines posing as humans are relevant again, as is Weber's question about the appropriateness of new applications.

\section{'People can feel that they are losing control of information which actually belongs to them. The public trust here is very fragile?}

All these smart systems raise other awkward questions. It's important to realise that they cannot function without collecting massive amounts of personal data about the users and their thoughts and actions. An incredible amount of detailed information on the user's actions, thoughts and emotions is now available, and the question is, to whom? Who should have access to this sensitive data? It's certainly the sort of information that will interest many parties; knowing what people do, think and feel is the ultimate dream of any marketer, not to mention certain actors in totalitarian states.

"Our personal privacy is very much being affected," warns legal expert Judit Sándor of the Central European University in Budapest. "People can feel that they are losing control of information which actually belongs to them. The public trust here is very fragile. We need to think about these issues on the long term." By way of a practical solution, Michael Rader of the Institute for Technology Assessment and Systems Analysis in Karlsruhe suggests introducing a system of licensing and procedures to control the data. "We have enough experience to develop them, but at the moment we are lagging behind..." [European regulators reading this, get your yellow markers out.]

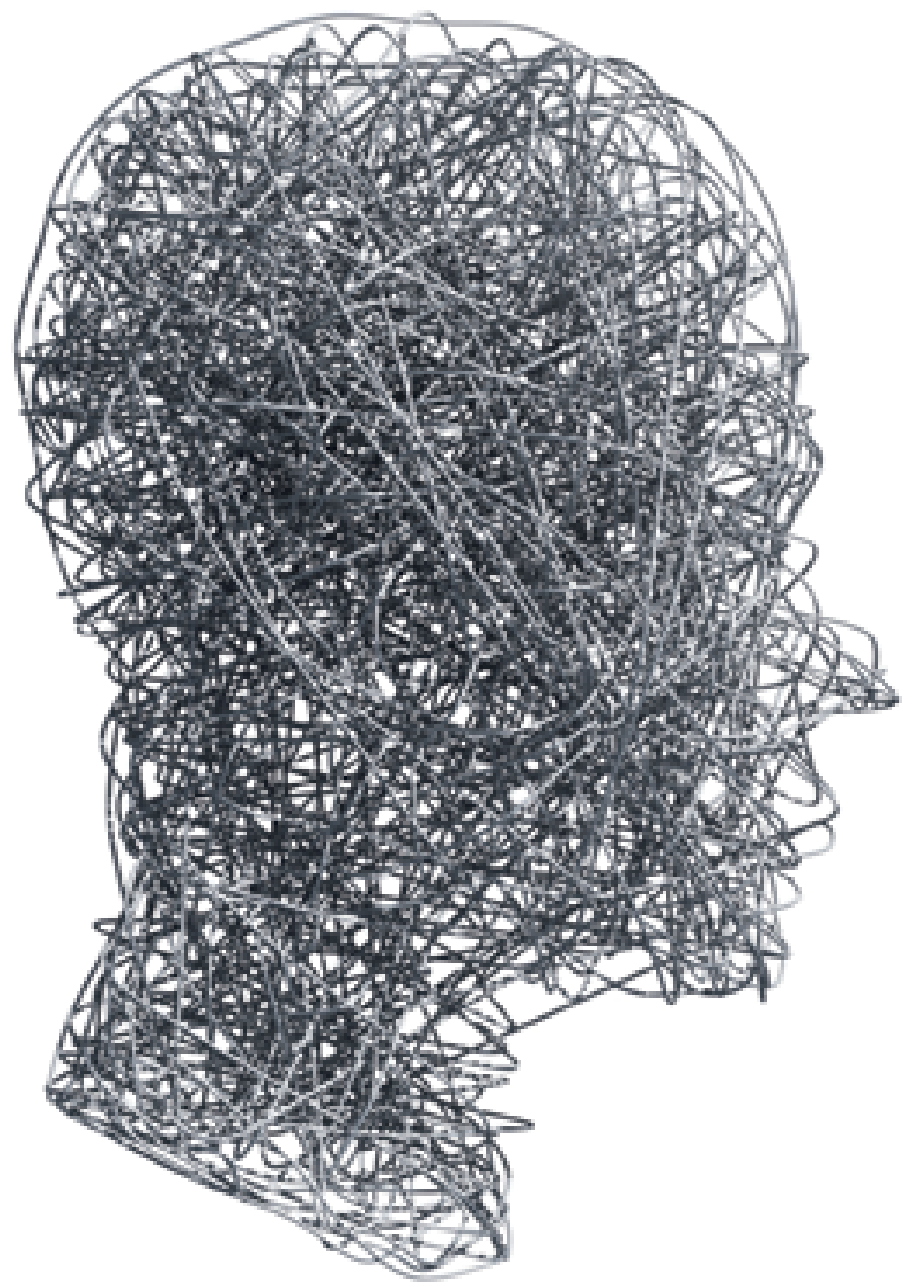


Equally awkward is what might be termed the fallibility issue. On the basis of information from sensors, these applications draw conclusions about people's moods, deeds and needs and take action accordingly. But their conclusions and actions are only as good as their software, which in turn is so complex that it is utterly impossible for programmers to predict how it will respond to every single eventuality. What happens when the computer makes the wrong decision? When dealing with a vulnerable person, serious or even fatal harm, is a possibility. Human actors also make mistakes of course, so it might be argued that as long as the machines do no worse than we do, no 'net harm' is done. But who is responsible for these 'automated mistakes'. Is it the manufacturer, or should the finger be pointed at the operator? European regulators will have to figure out what is just and practicable here.

\section{'Strong negative feelings among the general public are never far away, and metaphors such as 'playing God' and 'Frankenstein' - however clichéd- have lost little of their rallying power.'}

The second main area of bioengineering aims at modifying existing or even building new, mostly very small, life forms. Unlike 'traditional' biotechnology, engineers have set their sights on creating these from scratch. In practice, there is a continuum, with species being genetically altered at one extreme and entirely new ones being crafted at the other. Reading from left to right as it were, the 'biology-becoming-technology' trend is wellestablished with the number of newly introduced, artificial components and processes increasing and the number of natural components and processes becoming fewer. At the extreme right, where we see the opposite trend, the 'technology-becomingbiology' process is still in its infancy.

\section{Cellular chassis}

It is believed that in the future, the young discipline of synthetic biology will use synthetic genes as tools to transform cells into biological factories or agents with a highly artificial nature, based on a so-called minimal genome as a cellular 'chassis'. The long-term ambition is to create 'proto-cells' that would be self-sustaining and self-duplicating, starting from non-biological molecular building blocks. Useful features could then be grafted onto these proto-cells, or so the reasoning goes. At this point in time, however, it is extremely difficult to assess the potential of synthetic biology.

Obviously, the traditional worries about biotechnology also pertain to these developments.
Strong negative feelings among the general public are never far away, and metaphors such as 'playing God' and 'Frankenstein' - however clichéd - have lost little of their rallying power. It is not just the general public; ethicists are also struggling with the issues raised by 'creating life'. With bioengineering becoming ever more ambitious and possibly more potent, a new bio-debate seems in order. European politicians have a choice. Should they stimulate public debate in order to develop societal standards for living artefacts, which may result in a cautious acceptance or outright rejection of synthetic biology? Should they leave the fate of synthetic biology to market forces, hoping for more 'under the radar' introduction but risk a public outcry and loss of credibility later on? In a democracy, the question should be a no-brainer.

Other policy choices are of a more technical nature. Are the safety standards for biotechnology adequate for synthetic biology, or should new approaches be adopted? Does synthetic biology require special regulation of intellectual property rights to ensure a healthy balance of open access and protection? Should Europe stimulate the establishment of technical standards in synthetic biology, to help European players catch up with the now-dominant US?

'Old' biotechnology used to be about things like genetically modified crops and cloned farm animals. With bioengineering, we are now targeting our own species. The human genome was first mapped back in 2000. It is expected that within a few years, it will be possible to sequence the entire genome of any individual in a matter of days (and at well under a thousand euros, a not excessive cost). This is the current frontier for research: squeezing meaning out of the raw data that results from whole genome sequencing This is where biology is, yet again, becoming technology. Once the billions of As, Cs, Gs and Ts can be confidently interpreted, it will be possible to predict - among other things - the diseases an individual is prone to, and even to establish which treatment is best, given the rest of the person's genetic makeup. Personalised medicine is the name of this game.

The opposite movement, from technology to (human) biology, can be observed in current transplantation practices. While artificial implants, such as heart valves, have been commonplace for decades, the future might see implants manufactured on the spot by a three-dimensional printer. Artificial blood vessels are likely early candidates for this technology

Transplantation medicine also provides us with an illustration of the Escher-like two-way movement: after the biological surprise discovery that the cells of the human heart are capable of dividing after all, a technology was developed for cultivating new heart tissue on the basis of the patient's own cells. The method is being tested on pigs first. Stem cell technology presents another example. These forms of regenerative medicine hold considerable promise in terms of curing diseases and lengthening human life. 


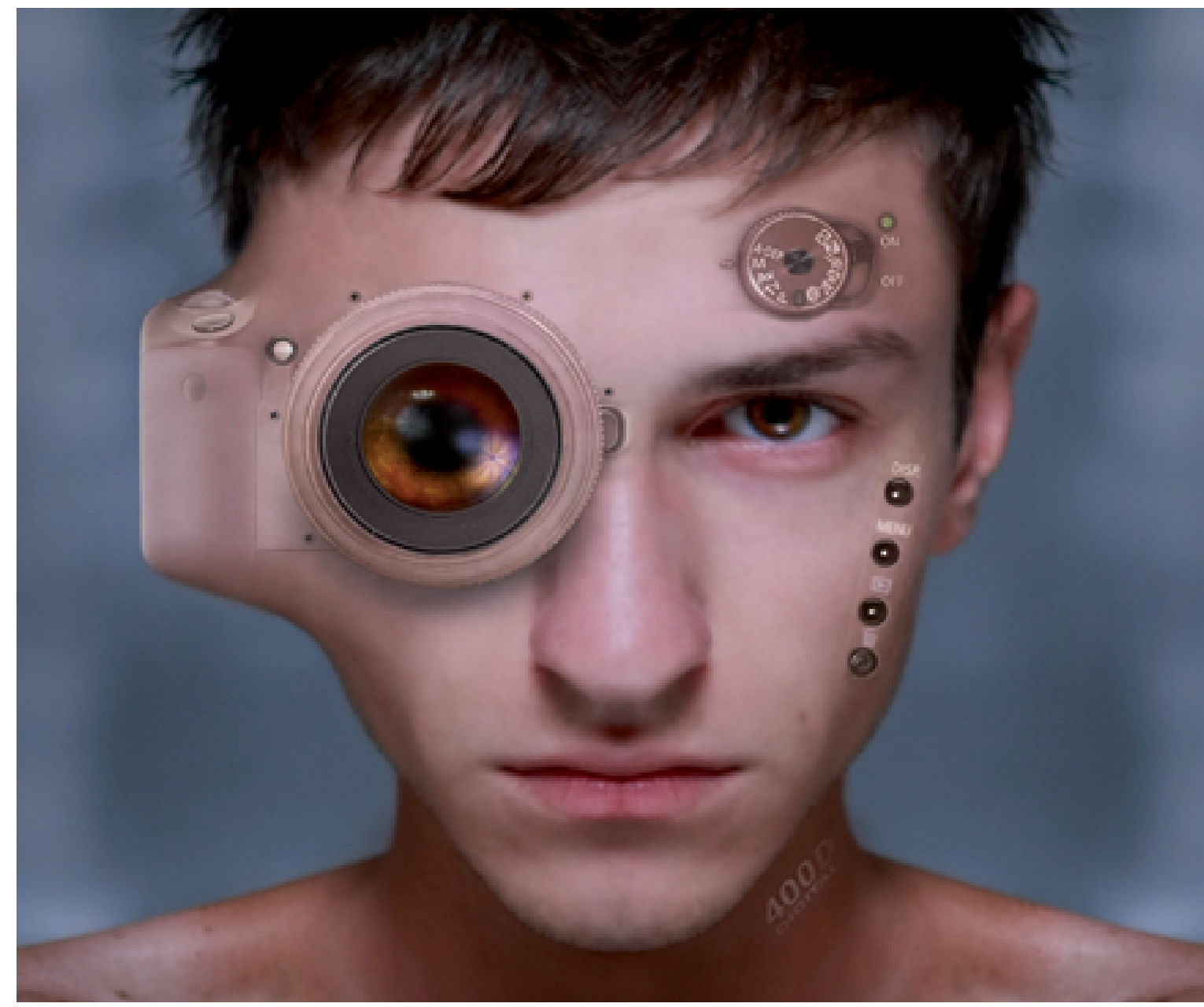

But privacy is once again, a huge issue. As with the use of intelligent artefacts, which allow the storage of an immense amount of data about an individual's thoughts, feelings and actions, sequencing genomes could leave people feeling completely exposed with nowhere to hide. The ability to interpret the genome will increase over time, so that seemingly meaningless data will reveal more and more. How do we deal with the DNA material and other personal data which will become available in the coming years?' According to Bärbel Hüsing of the Fraunhofer Institute for Systems and Innovation Research in Karlsruhe, more guidelines and standards are needed: "With the expected increase of data exchange and internationalisation, the biomedical field needs to adapt a code of conduct on how to share these data. What level of confidentiality is needed here? How are we going to handle biobanking and personalised medicine? My personal view is that more international harmonisation of regulations by the European Union is desirable."

While a number of specific developments were studied in the project which exemplify the major trends in four fields of bioengineering, the purpose was also to alert politicians. Despite the long-term character of the megatrends, near-term policy challenges and regulatory questions in these specific developments are already imminent. 
Two questions frequently crop up in discussions about new medical technologies. The British Conservative MEP Malcolm Harbour voiced one of the most fundamental: "When we discuss the issues of prolonging human life, the question remains: how far do we want to go?" The other question is equally fundamental and unavoidable: how much is society willing to pay for health care to cover an ever longer life? When this willingness reaches its limits, how do we deal with the inequity that arises when the rich can afford treatments that the rest of us don't have the money for?

\section{Interventions in the brain}

If you feel queasy thinking about someone manipulating your brain cells, brace yourself for what's coming next. Your brain, the delicate organ where many of us feel our inner self sits enthroned, may not only get copied, but in some individuals, is already being regulated by technical devices. In The Blue Brain Project, technology is currently aiming to emulate biology. Although not all specialists in the field believe the idea of using computer simulations to understand cognitive functionality to be feasible or even particularly promising, the whole idea would have been inconceivable not very long ago because of sheer lack of knowledge about the brain. First, it was experiments on animals that yielded a good deal of information. And now more direct knowledge of the human brain is being gleaned thanks to diagnostic and therapeutic technologies including several types of brain imaging and stimulation.

Three of the major technologies here are Deep Brain Stimulation (DBS), Transcranial Magnetic Stimulation (TMS) and EEG neurofeedback. The aim of these technologies is (for now...) therapeutic: they are used for Parkinson's disease, severe depression and ADHD, respectively. The use of these technologies is likely to be extended. For one thing, further therapeutic applications are being investigated, e.g. against epilepsy in the case of EEG neurofeedback. For another, it is very likely that healthy (or 'neurotypical') people could also benefit from neuromodulation by having their mood or cognitive performance enhanced, while EEG neurofeedback might well come to play a role in gaming.

This is where things get interesting from a regulatory perspective. The existing regulations for neuromodulation were drawn up exclusively for the medical domain, under the assumption that the devices would be operated and maintained by qualified personnel. But once new technologies get in the hands of less-qualified operators or ordinary consumers, new requirements are needed to keep users out of harm's way. Even with trained personnel in place, there have been cases which should raise alarm signals. EEG neurofeedback has caused anxiety and insomnia; TMS can sometimes lead to hypomania, headaches and hearing loss.

\section{'Bioethics is ultimately toothless without biopolitics'}

Once these technologies 'get on the loose' in society, there is an evident regulatory gap in urgent need of filling. It won't do just to routinely declare them applicable either, because in other domains, the circumstances of use, the needs and even the risks may be different. Rather than wait for the devices to get on the market, politicians should consider the regulatory framework while these products are still under development. It's important to note that this is not only true for medical applications of neuromodulation. All of the other technological trends described above could spread to new, unexpected fields, such as gaming, surveillance, nursing and forensics, to name but a few. Regulators are well-advised not to take a complacent or wait-and-see attitude.

Speaking as a vice-chairman of STOA (the Science and Technology Options Assessment unit of the European Parliament), MEP Malcolm Harbour notes: 'The task for STOA in the European Parliament is now to disseminate the conclusions

\section{The Making Perfect Life project}

\section{Research}

Research has been carried out since 2009 by four memberorganisations of the European Technology Assessment Group (ETAG):

- Institute of Technology Assessment (ITA), Vienna (Austria);

- Rathenau Institute, The Hague (Netherlands) (project co-ordinator);

- Fraunhofer Institute for Systems and Innovation Research, Munich (Germany);

- Institute for Technology Assessment and Systems Analysis (ITAS), Karlsruhe (Germany).

\section{What makes it special?}

- By looking at interlocking bioengineering developments it brought to light deeper trends than would otherwise have been possible.

- It examines how technological developments could spread beyond their traditional fields of application rather than mapping expectations of where technology is heading and listing problematic aspects.

- It analysed how the new technological wave is challenging the existing way of governing science and technology at a European level and the governance challenges of 21st century bio-engineering. 
of this wide-ranging and complex study, and to focus the findings on relevant policy issues.

Now that the STOA secretariat forms part of the Parliament's wider directorate on Impact Assessment and European Added Value, this should help ensure a joined-up approach to policy evaluation and new policy initiatives.'

By weighing up the ethics of bioengineering, we can address issues for the benefit and protection of ordinary Europeans, but it's up to politicians to actually do it. As project leader van Est puts it: "Bioethics is ultimately toothless without biopolitics."

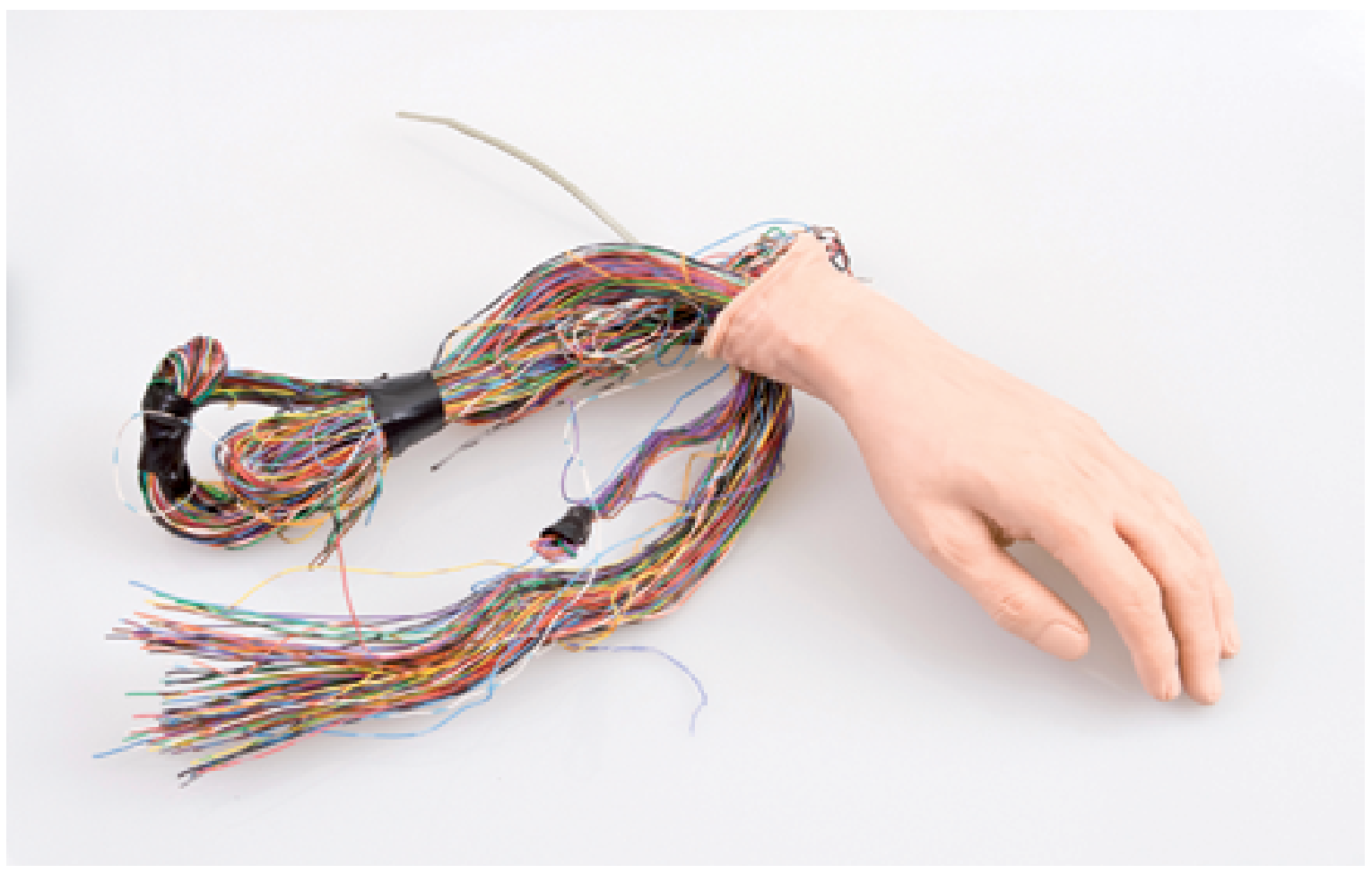

\section{Significance for policy makers}

'The Making Perfect Life study has been one of the most ambitious and wide ranging projects that the STOA Panel of the European Parliament has carried out. It highlights the need for a wider dissemination of the issues and for developing the policy mechanisms to respond'

Malcolm Harbour MEP, vice-president of STOA.

\section{Further reading}

Van Est, R. \& D. Stemerding (eds.) (2012) Making Perfect Life: European governance challenges in 21st century bio-engineering - Final report. Brussels: European Parliament, STOA.

http://tinyurl.com/MPL-finalreport

Van Est, R. \& D. Stemerding (eds.) (2012) Making Perfect Life: European governance challenges in 21st century bioengineering - Study summary. Brussels: European Parliament, STOA.

http://tinyurl.com/MPL-studysummary

Van Est, R. et al. (2011) Making Perfect Life:

Bio-engineering (in) the 21st century - Monitoring report.

Brussels: European Parliament, STOA.

http://tinyurl.com/MPL-monitoringreport 


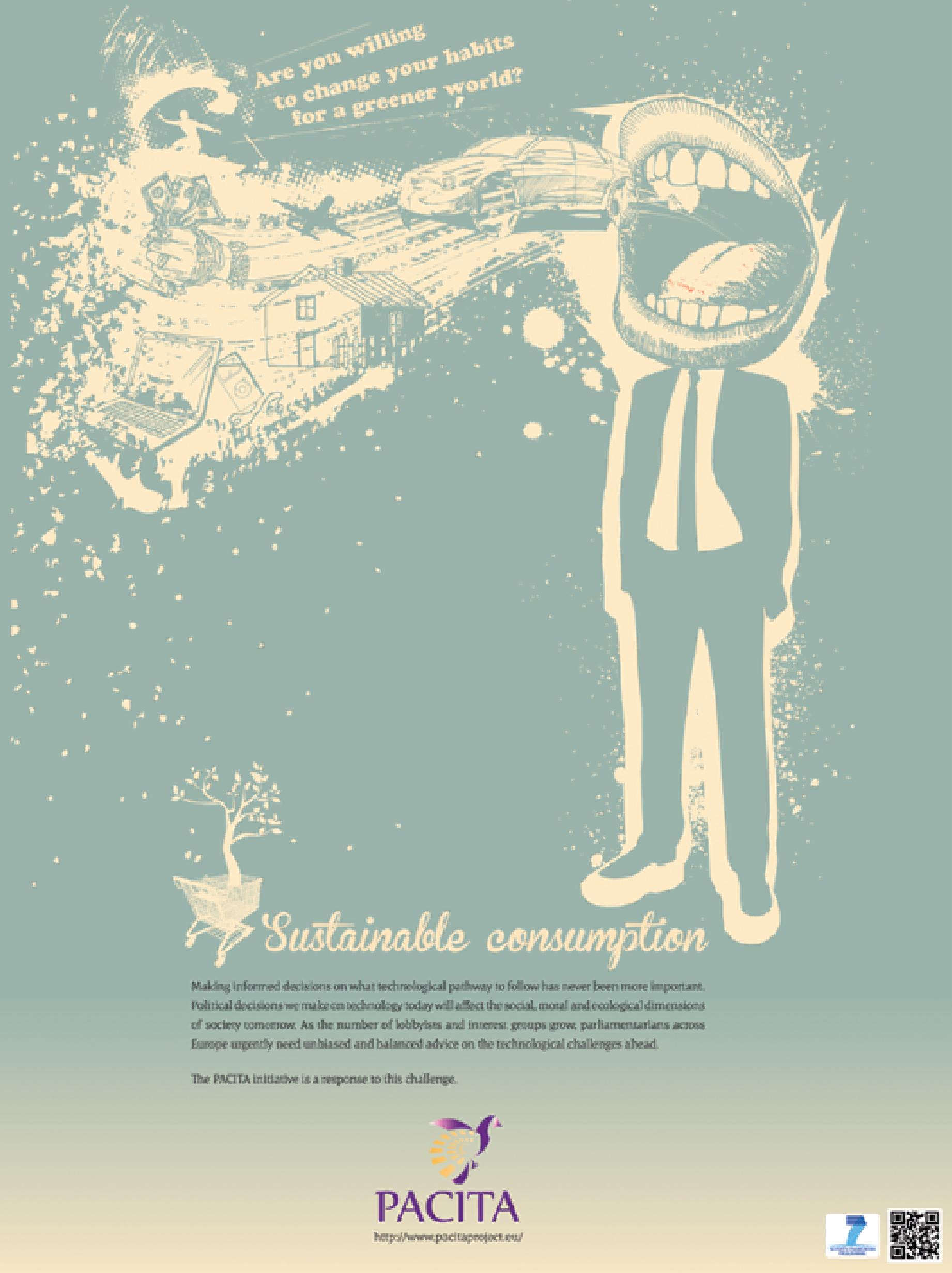




\section{Getting politicians, scientists and stakeholders together at an early stage to discuss a specific topic opens up the debate and hopefully leads to more robust policy making. In the PACITA project, a Future Panel is dealing with the challenges related to public health genomics.}

\section{'A future panel requires visionary thinking that crosses the boundaries of different sectors, spheres of competence and professional disciplines'}

Public health genomics is a clear example of a topic with governance implications across many spheres. "It touches on transnational issues such as data sharing and informed consent, as well as the clinical validity and utility of genomic tests," explains André Krom from the Rathenau Institute in the Netherlands. It's also a method that aims to create a long term engagement with a topic and the issues under discussion. Over a two-year period, several opportunities are created for the feedback of results between politicians, policymakers and the scientists. Even better, there are opportunities for constructive interaction.

Members of a future panel are selected on the basis of their political status. They are current members of parliament in national member states, and importantly, their political responsibilities must include the topic under discussion.

As coordinator of the future panel on public health genomics, Krom sees major benefits in including members of parliament at an early stage. One of these is that parliamentarians provide direct input into the research process. Maintaining close ties between policy and research enables the research output to be fed back into the policy making process. "Of course, we hope that our future panel members can act as ambassadors of the issues raised by developments in the field of public health genomics in their respective parliaments," explains Krom, "but members of parliament do not have to do the job entirely on their own". In line with the idea of expert-based policy-making, members of parliament are joined by colleagues from the clinic, the lab, the market, and by experts covering the ethical and legal aspects of public health genomics. "Part of the PACITA methodology is to combine the insights of politicians with those of policy-makers and scientists," says Krom.

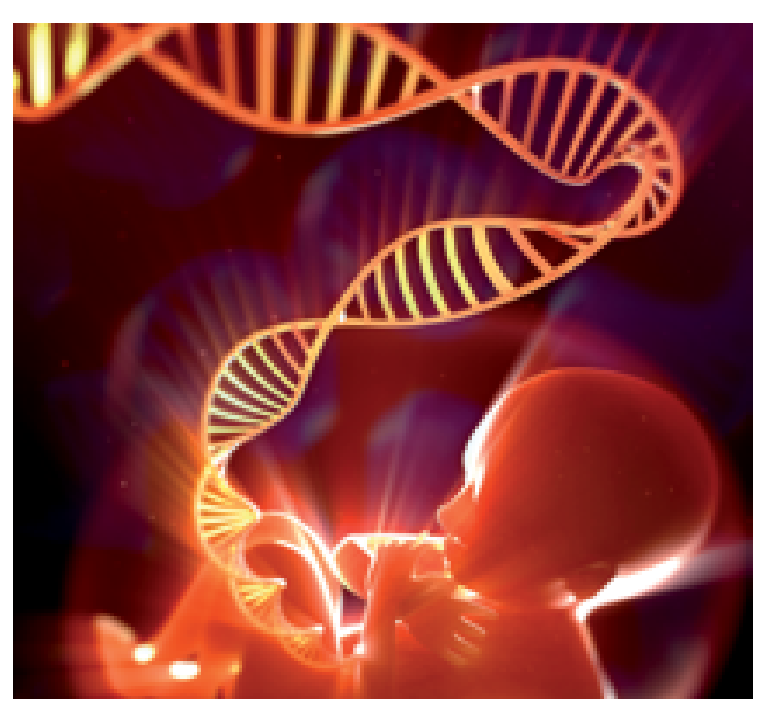

The members of parliament can contribute real issues that arise from their daily political environment. Consequently, scientists will interpret these as being closely connected to what is considered to be relevant from a policy-making perspective. But this method is not without challenges. For instance, members of parliaments are often responsible for other, potentially conflicting, topics. The transition from 'public health genomics' to 'the public debating health genomics' needs deliberation but it's a transition that should be acknowledged, according to Krom: "In my opinion, it is clear that the broader public should be included at some point. If we are talking about public health genomics, we are talking about using genomics to protect or promote the health of the (broader) public."

\section{Read More?}

The emerging field of Public Health Genomics intends to integrate genome-based knowledge and technologies into public policy and into health services.

Further information on the PACITA Future Panel can be found on the website www.pacitaproject.eu

More information on how future panels work is available from the Danish Board of Technology:

www.tekno.dk/subpage.php3?article $=815 \&$ language $=u k \& c$ ategory=12\&toppic=kategori12 


\section{António Barreto on freedom of information: Numbers are not enough}

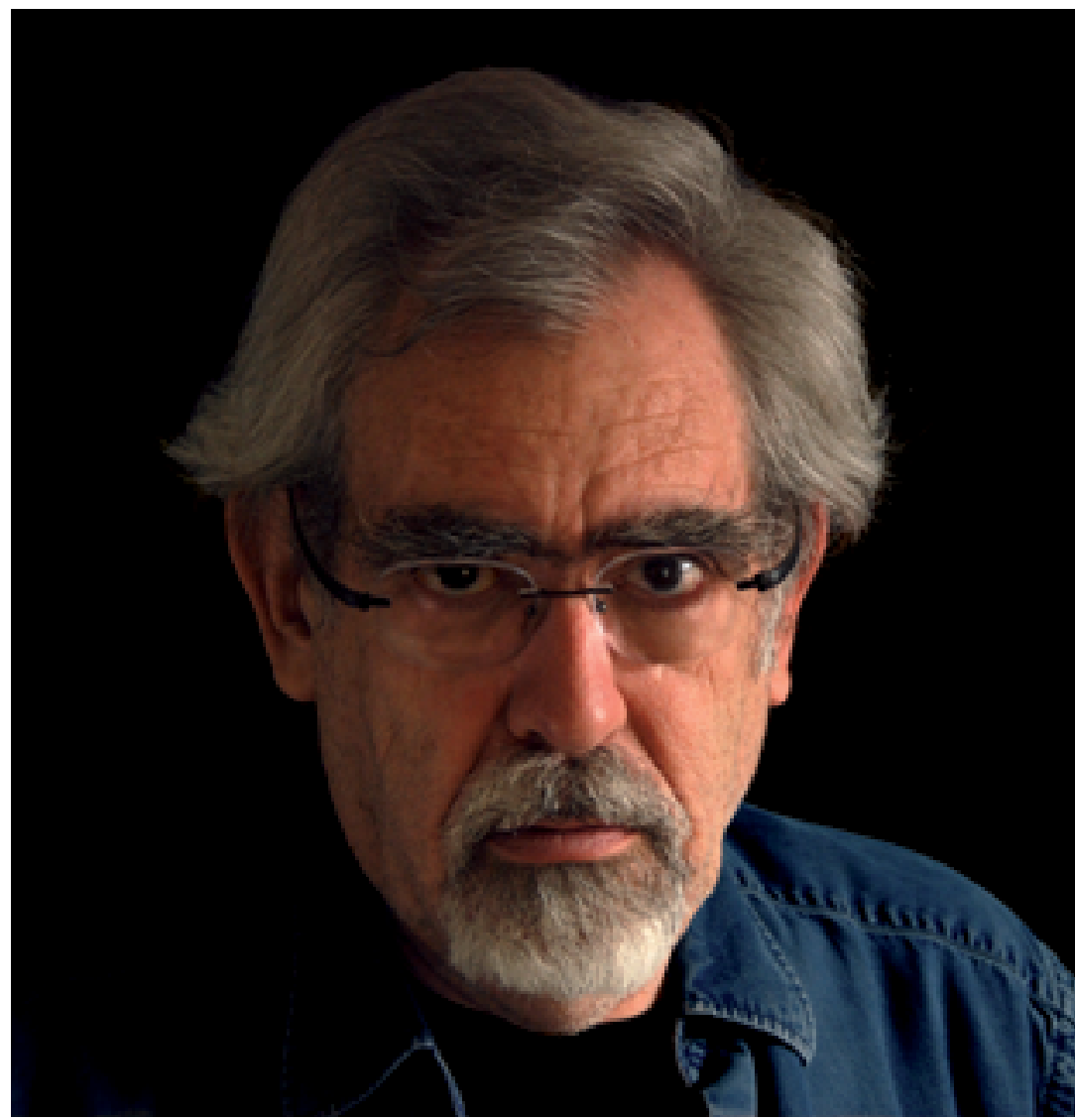

'I could draw a definition of you based on a million different statistical indicators, and I still wouldn't be able to draw a reliable portrait' 
"We have elected individual freedom as our main mission at the Francisco Manuel dos Santos Foundation," explains Portuguese sociologist António Barreto, Chairman of the board of directors of the Lisbon-based private philanthropic foundation. For Barreto, that means free access to knowledge, like the certified statistics provided through his PORTADA database: "We believe that knowledge is a way for individual freedom and social development. But numbers are not enough. Critical thinking also plays an important role".

PORDATA systematizes free-access certified Portuguese statistical information based on more than 20 reliable sources, such as the National Institute of Statistics (INE), going back over more than 50 years. There are several different databases in the project. One for Portugal, another for Europe (meaning the 27 EU countries based on similar indicators), and a third one which assembles social, economical and demographic indicators related to all cities in Portugal, with cartographic search engines. A new database, with economical indicators on Portugal, is about to be launched. According to Barreto, "This is something completely new, that did not exist at all until now. It has only become possible because of changes in the processes and terminology over the last 40 years. We are working with a team of very experienced consultants and we expect to make it available online very soon. Plus, we are also working on another database project that will gather worldwide information. That is to say, global data on I 70 different countries, although we are facing difficulties concerning countries like Angola, where they still haven't started to gather their national statistics information. Also, we sometimes face problems related to quantity and ideological criteria when dealing with human rights".

\section{'I personally feel quite tired of people who only consider numbers when studying a country, or a culture, or a specific people?}

Barreto takes an original approach when it comes to what determining what information is significant. "There is an indicator which I particularly like called 'freedom to walk in the streets by night'. There are less than 40 countries where you can actually gather that kind of information concerning public security. There are still big differences between the countries in the world, making it impossible to build a universal database that can actually work for every indicator. Still, it is worth starting with what we have and might have in the near future". This includes gathering and comparing public opinion information on diverse subjects in different EU countries, from racism to gender issues: " It helps us understand how confidence in democratic institutions is developing in each country", according to Barreto.

But isn't there is a great deal of subjectivity when it comes to that kind of opinion analysis? "I agree, but I also think we shouldn't only work on pure statistics. I personally feel quite tired of people who only consider numbers when studying a country, or a culture, or a specific people. Statistics are not enough. I could draw a definition of you based on a million different statistical indicators, and I still wouldn't be able to draw a reliable portrait of you. Humanity is complex which is why I think we should consider more subjective indicators, such as opinion, when studying countries.”

In order to work with ideas as well as numbers, Barreto's organisation decided to become 'editors'. In order to reach people, knowledge access needed to be free or low-cost. Some 3,000 people in Portugal access PORDATA daily. "We don't really know who uses it", says Barreto, "but we do know how people use it. Whatever concerns family, children, marriage, divorce, seems to interest the Portuguese very much”. Social issues - housing, public medical care, unemployment, etc - are also important. "We know schools are using PORDATA a lot, together with public services (state employees) and some countries such as France, Spain and the UK use it a lot. The average number of visitors is growing every day". The Foundation recently hosted a conference in 2012 on Portugal in 2030 which attracted $\mathrm{I}, 500$ participants.

\section{Knowledge for Free}

But how is this free-access knowledge advertised? How do citizens become aware of PORDATA, for example? "We advertise as much as we can through the Internet. We also announce everything we do to journalists, via press conferences. When we began working, we produced 60 short videos of two minutes each that were shown during the evening news on TV using our database - different statistics on Portugal every day. But there is another thing we do that really helps make PORDATA to be spread in Portuguese society: we have a team of instructors that are available to any Portuguese (or other) institution that wishes to learn how to work with PORDATA. We offer that training for free."

Although PORDATA trained some I 40 journalists at the national broadcaster RTP (Rádio Televisão Portuguesa), the take up by universities and secondary schools has been less successful: "We offered free training to more than Ioo faculties and schools, but

António Barreto (born Oporto 1942) has been Chairman of the Board of Directors of Fundação Francisco Manuel dos Santos (FFMS) since 2005. He lived in Switzerland as a political exile from 1963 to 1974, studied Sociology at Geneva University and returned to Portugal after the Carnation Revolution. As a Member of Parliament for the Socialist Party, he held positions as Secretary of State for Foreign Trade, Minister for Trade and Tourism, and Minister for Agriculture and Fisheries. He was awarded the Montaigne Prize in 2004 by the International Council of the Alfred Toepfer Foundation (Germany) for his achievements in sociology research in Portugal. He has published several books on Portuguese social history, was co-author of the Dictionary of Portuguese History 1925/1974 (1999) and author of the television documentary Portugal, um retrato social (Portugal, a social portrait, 2007). He is also a well known photographer. 
we had only three candidates.” Barreto would also like more response from Portuguese parliamentary political groups: "This worries me, although I know they sometimes refer to PORDATA statistics when debating at the Parliament."

The Fundação Francisco Manuel dos Santos is a private philanthropic organization and its key sponsor, Alexandre Soares dos Santos, is the owner of a supermarket group. Isn't that a little unusual? Barreto tells the story: "Sometime ago I was at home and $\mathrm{Mr}$ Soares dos Santos paid me a visit to announce his family intention to build a foundation dedicated to study the reality of life in Portugal... He asked my opinion and if I could give him a help in drawing up some kind of plan." When offered the job of president, Barreto agreed but with conditions. "I was happy to accept but took some precautions, such as making it legally impossible to work on information that could interest the group itself," he explains. "We don't do market studies, we don't analyse consumption trends based on what is sold at the stores of that specific supermarket group. We had to be independent.” The Foundation operates on a regular annual budget and currently only two people on the board represent the Soares dos Santos family.

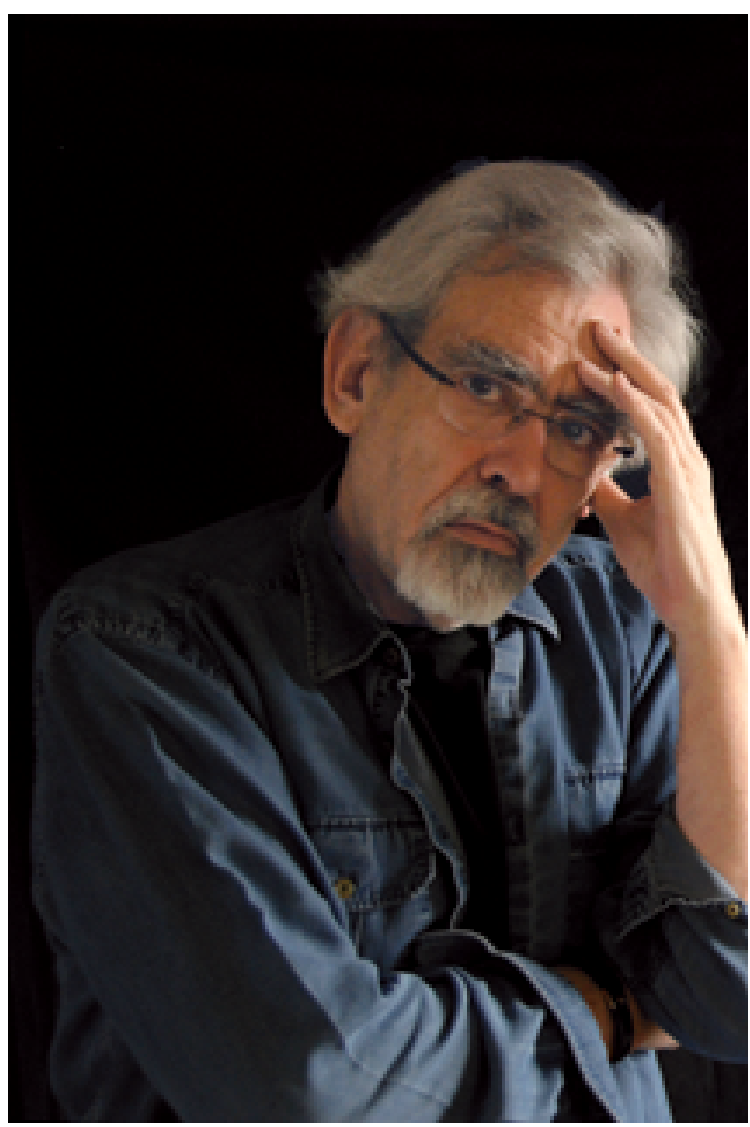

But decreasing consumption is on the economic agenda of many European countries, so how will the Foundation deal with that? Barreto talks about China: "We know that we cannot continue with the same old energy policies at a time when China is at its best (meaning worse) concerning energy. China now wants in the next Ioo years to do what the western world has been doing for the last 200...China bought a great deal of the American national debt, and is now buying European national debt, which is, as you know, a way of buying political power. But yes, we might get caught ourselves in the middle of that decreasing consumption process in Europe and that is something we have to accept as a part of the reality we are working on. Concerning environmental issues, PORDATA has a specific database with some Portuguese indicators. We also published a book on global climate changes. Still, there is work to be done on those important issues. Portuguese people have been very poor for a long time, and I think there is a clear link between that circumstance and some indifference towards environmental issues”.

"I remember coming back from Switzerland in 1974 and discovering the Portuguese didn't seem to care at all about that. Cities were filthy, they would finish building a house and everything would stay dirty and messy for a long time, nobody seemed to care. I remember seeing (and smelling!) garbage dumps that would just stay there for years, without any recycling and cleaning. Things are better nearly 40 years later, but there is still work to be done. Movie director Manoel de Oliveira even filmed one of those horrible dumps near Oporto. Still, I think younger people tend to care about that a lot more - and I hope that with their awareness we will not leave them an impossibly polluted world."

\section{'Mentality is something hard to evolve - it is the last thing to change in any human society'}

Every day, people can pick up a free newspaper at a subway station that contains information from PORDATA. Does free access to knowledge make a difference to how citizens view their society?

Barreto is cautious, but hopeful: "I am quite sceptical about the visible consequences of our actions. What we do concerns values and behaviour, and as far as I know, changing mindsets is harder to evolve. Politicians try to address this in their political speeches but promising a change is absurd. You can easily change infrastructures such as roads, and you can also turn new technology into something that changes people's habits easily, because money can buy that. But changing mindsets is something different, because you are dealing with values, knowledge, thought, and for that you need several generations I think. Material society changes fast, but what we do at the Fundação Francisco Manuel dos Santos deals with slower issues. I am sceptical but also positive because I know we are working for future generations." 


\section{What are the new, emerging topics that matter to European citizens? How can policy makers ensure future research and development agendas in Europe address these concerns? The CIVISTI project consulted citizens from seven European countries to uncover their visions for the future.}

'I hadn't expected such a commitment to the future and such a commitment to the evaluation of that future' CIVISTI participant. their long-term science, technology and innovation policies, they came up with a new and experimental approach. In the CIVISTI project, citizens in Denmark, Austria, Belgium, Finland, Malta, Bulgaria, and Hungary were consulted to find out what they thought about the future. Since decision making often happens over a long-term basis, it can be difficult to combine knowledge from both citizens and experts to support such processes. The CIVISTI project marked a new and exciting methodological approach - 'participatory foresight'.

In CIVISTI, citizens acted as consultants, hired to help European decision makers prepare the next research program, Horizon 2020. They had an important role to play: defining relevant areas for research would often gain from the consultation of citizens. Citizens have expectations and concerns about the future that can be transformed into relevant research and policy agendas. This is just what happened through CIVISTI.

Citizen panels were organized in seven European countries. The first step in the project was for these panels to formulate their visions of the future. These covered a broad range of topics, including ageing, agriculture, democracy, energy and education. In total, the citizen panels produced 69 visions. Experts and stakeholders then analyzed these visions and transformed them into policy agendas for European research. In the third and final step, the citizens validated and prioritized the recommendations formulated by the experts. In the end, 30 recommendations were made from the 69 visions. Of the citizens' top ten, 'attractive public transport' ended up as number one.

The CIVISTI method was repeated in Austria after the original CIVISTI project was over. Mahshid Sotoudeh works at the Institute of Technology Assessment (ITA) at the Austrian Academy of Sciences that was one of the CIVISTI partners. She
When the European Commission wanted input into used the CIVISTI method during an internship at ITA for the 'Rio +20 ' project where a group of students, aged I6-I 8 years old, expressed their visions, fears and hopes for a sustainable future. Their 'Newsletter from the Future' painted a picture of how today's research efforts can create a more sustainable world and which research topics need to be addressed. Later that year, they received a 'Creativity Prize' from the Federal Ministry for Science and Research in Vienna for their work, the jury highlighting their optimism and the creativity of their text.

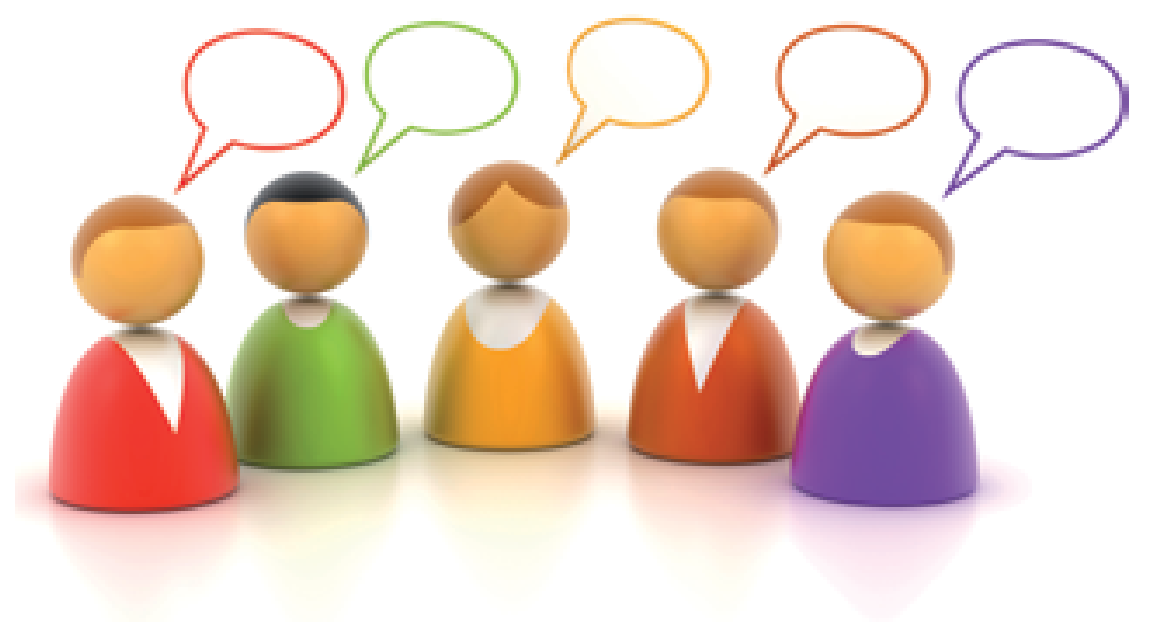

The CIVISTI project started out with a 'learningby-doing' attitude. Giving citizens a voice in an area usually dominated by experts - the creation of research policy - had never been done in this way before. But it proved to be most successful. The project received positive feedback from citizens and experts as well as academia and decision makers.

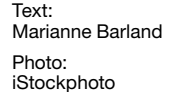

Photo:
iStockphoto

\section{Read More? \\ The CIVISTI project: http://www.civisti.org \\ Horizon 2020: http://ec.europa.eu/research/horizon2020/ index_en.cfm}




\section{Wavy wonder}

\section{Zsuzsanna Szentirmai-Joly is the inventor of Laokoon ${ }^{\circledR}$, a fabric that moves. Inspired by fish and reptile scales, beautiful two and three- dimensionsal forms can be created for a myriad of applications including fashion, furnishings, interiors and art.}

Text:

Katalin Fodor

Photos:

Francois Joly (Portrait)

Horváth Dániel

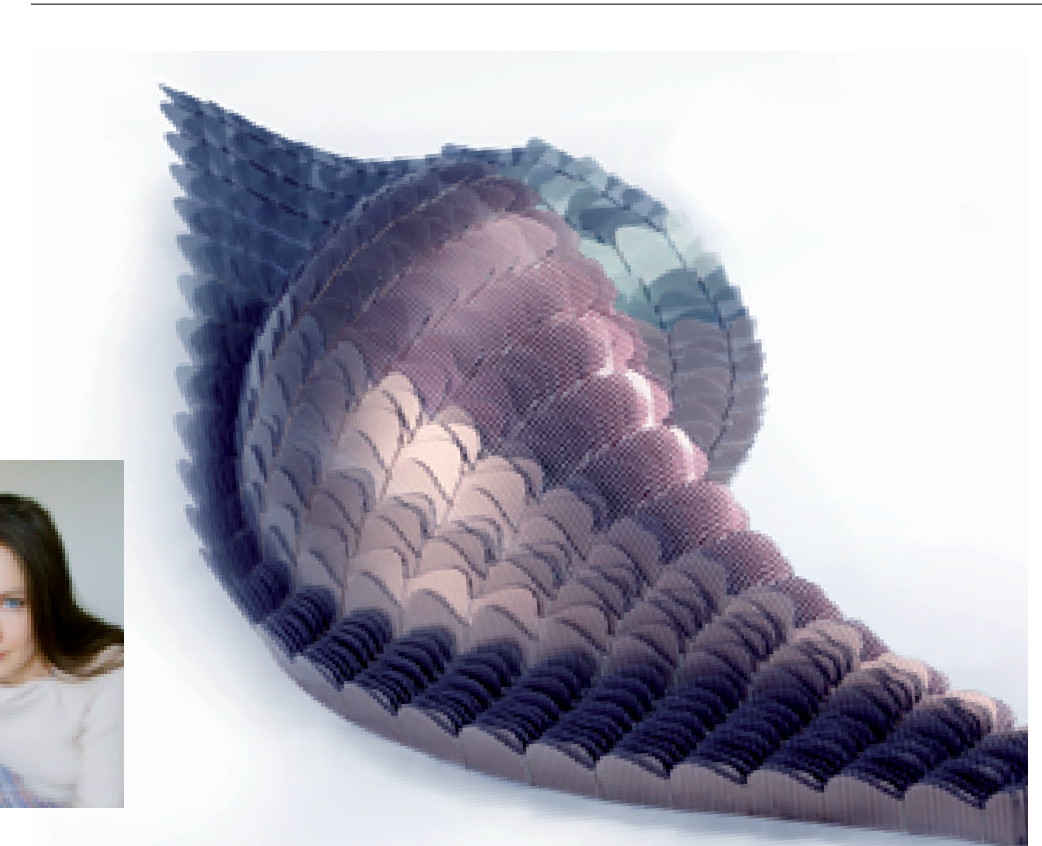

Present state of mind?

My life has been full of incredible excitement lately. There are miracles and tragedies happening on a daily basis. I am filled with hope but I am realistic. Not bored for sure.

\section{Biggest success?}

I hope that my biggest success is yet to come. For the time being I am most proud of our achievements at the 100\% Design exhibition in London. Having collected a vast number of exceptional contacts is encouraging recognition and builds faith in the future.

How did you get where you are? Ambition, strong will, perseverance, courage and many, many supporters who backed me up.
Akram Khan's and Farooq Chaudhry's relationship sets an outstanding example for the ideal synergy between artist and arts manager. I admire Adam SomlaiFisher, the founder of Prezi, who, besides his arts career, has achieved such a great success in business that has contributed to framing the image of Hungary. And of course I could cite many more!

\section{Failures?}

Certainly, I have to face them every day. The road to success is not straight and not guaranteed. You have to train yourself, you have to endure or simply be able to handle hardships more naturally.

Plans for the future? Dreams? I would like Laokoon ${ }^{\circledR}$ moving structure and the products made

from it to bring professional and financial success. One is not worth much without the other. Right now I am working on building up the team that is necessary to reach those goals. I would be glad if the applications could go beyond the boundaries of design, fashion and architecture and used in completely different fields such as robotics. I sincerely hope to find partners to accomplish my ambitions.

\section{What will it take?}

Lots of work, self-discipline, planning, learning, courage, perseverance, attentiveness and of course a good deal of luck are all necessary to make great dreams come true.

\section{Fears?}

Of course, but I'd prefer not to talk about them. I don't want to feed them and let them gain strength.

\section{Inspiration?}

Articles, presentations, trade fairs, exhibitions, good conversations...

\section{What would you change?}

I would like to change the whole world, but I had better focus on what is within the sphere of my influence so changing my own unfavorable habits and learning from my mistakes.

You can see the work of this artist at
the exhibitions Maison et Objet 6-10
September 2013, (Nord Villepinte,
Paris) and 100\% Design 18-21
September 2013 Earls Court, London)
For more projects and information:
http://www.laokoondesign.com

You can see the work of this artist at the exhibitions Maison et Objet 6-10 September 2013, (Nord Villepinte, Paris) and 100\% Design 18-21 For more projects and information http://www.laokoondesign.com 


\section{Scientific ethics in China, the need for senior citizens to be independent and the German TA approach that impressed the man from Japan, were just a few of the topics under discussion at the PACITA conference in Prague.}

'Our states, parliaments, and indeed democracies, need to be reinvented by experimenting with new forms of participation, expert advice and decision making'

Wiebe Bijker, Keynote speaker.

Eclectic. That is probably the best word to describe the Pacita conference that took place in Prague (I3-I5 March 20I3). Under the banner Great Transitions, specialists from all walks of TAlife gathered to discuss their profession as part of the four year PACITA program. Almost 200 presentations crammed into three days giving the attendees a crash course in current developments in modern Technology Assessment. From innovations in healthcare for the elderly in the Czech Republic to the (hotly debated) development of science ethics in China; to the necessity of electric transportation in Portugal, and the potential hazards of bioengineering everywhere. The conference in the Czech capital was nothing if not a mixed bag.

\section{German clusters}

An excellent example of a real great transition is the work of the German Steinbeis-Europa-Zentrum (SEZ). At the conference they presented their study on the so called cluster approach of the German government. In short, clusters are groups of research institutions, companies, universities and other agencies that bid on government grants to come up with new technologies and innovations.

As the SEZ research shows, the secret of a successful cluster is cooperation within a value chain. All links in the chain must get something out of the project. A good example is the design of new infrared sensors that will make cars more fuel efficient. A number of research institutes and the industrial behemoth Bosch are working together to design the new generation of sensors. All players are very committed and state that they communicate well.
According to the SEZ investigation, this minimizes the risk of the project failing.

How does a cluster come into being, asked a Japanese guest? He said he has the intention of copying this method in his home country. A contest is a good starting point, said Herr Clar of the SEZ. Governments should organise competitions for any large-scale innovation projects that are only open to clusters. This way, you force various parties to cooperate and discuss their ambitions at an early stage in the project.

Over in another room at the national technical library in Prague, another group of TA specialists was concentrating on presentations covering a very different, but equally important transition: dealing with an aging population. The European baby boom generation is reaching their golden years and many countries are faced with the question on how to handle that demographic development in a responsible way.

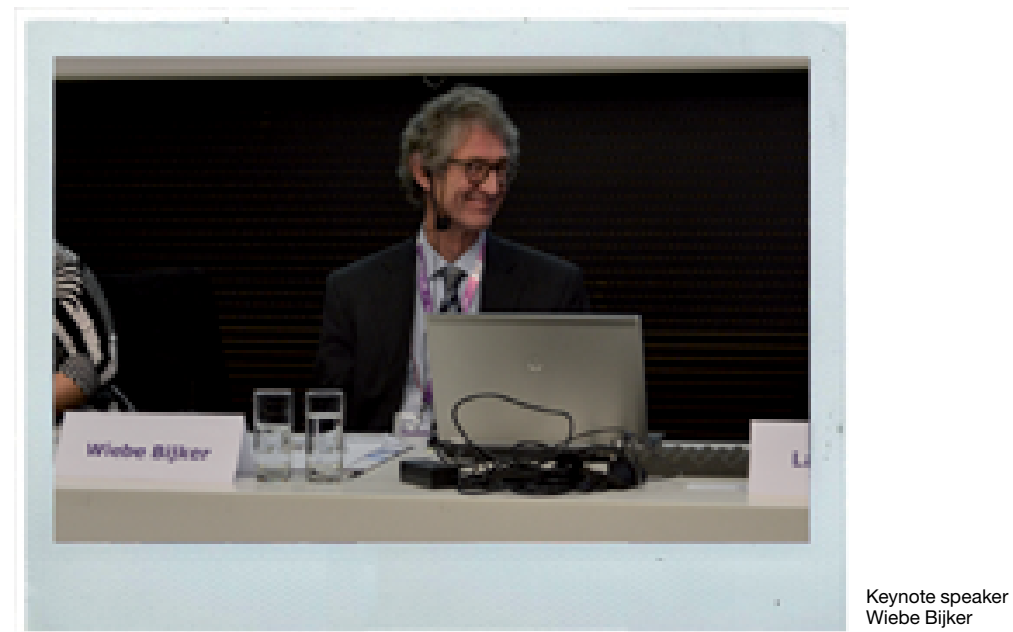

A Czech research project discovered that modern seniors value autonomy above anything else. They want to be self reliant, stay in good health and eschew the concept of a nanny state which tells them how to live. No surprise there, but how does a state meet these demands? As the Czech researcher stated, 
about 25 percent of the over $85 \mathrm{~s}$ are suffering from dementia. These people might not be capable of living autonomously.

The same research showed that one way is to forego the paternalistic approach that was prevalent until recently. The whole life of a senior citizen must be taken into account (was he or she very independent prior to the onset of dementia?) in trying to find out what kind of care fits each individual. The elderly should not be treated as a homogenous group; decisions should be based on individual need. Technology can help reach those goals, a delegate from the Netherlands added, but only if it is specifically tailored - and designed with the help of senior citizens.

\section{Know your client}

Obviously, most Technology Assessment is undertaken for the benefit of policy makers. How do TA-professionals service these demanding clients? What do policy makers think of TA? A major session under the chairmanship of old TA hand David Cope compared projects in Finland, Germany, Denmark and the Netherlands. The session was somewhat hindered by the absence of sufficient politicians. A German member of parliament cancelled at the very last moment, leaving the German TA-professional to discuss the matter with himself.

\section{'A new paper on nanotechnology is published every eight minutes'}

Still, Cope managed to get a good discussion going. TA means different things in different countries. German TA stays very close to parliament, even to the extent of being assigned projects by individual members of the Bundestag. The independent-minded Dutch keep politicians at an arm's length, but do work together if circumstances so require. The Danes are very service-oriented. In the words of Bjørn Bedsted of the Danish Board of Technology: "Search out your client. Ask him what he wants and prepare your reports accordingly." His client, division head Søren Jensen of the Danish ministry of Environment, smiled in agreement.

Not all presentations were that hands-on. Sometimes a very high degree of abstraction was reached. In a very interesting clash of intellects, sociologist Joy Zhang of the University of Kent (UK) went head to head - figuratively speaking - with sinologist Ole Döring of the Horst Görtz Institute in Berlin and anthropologist Aditya Bharadwaj of the Graduate Institute of International and Development Studies in Geneva, Switzerland.

Zhang is the author of the acclaimed book Cosmopolitization of Science, which assesses the development of bio-ethics and technology governance in China, especially in the field of stem cell research.
During a very strong presentation, Zhang made clear that China is no longer the 'wild east' when it comes to science and ethics. For her book she visited 22 research teams in China and she came to the conclusion that they are now part of the international science community. Döring and Bharadwaj were invited to critically assess the book. Both started out with lavishing praise on the work of Zhang, believing, like her, that the time of 'us' against 'them' is over. To quote Döring, it is the time for building bridges across cultural divides, so science can reach its full potential.

That did not mean there was no criticism. Döring did not like the very matter-of-fact methodology of Zhang. Her tome is - in his words - 'not a TA book'. He would have liked for her to have reached more outspoken conclusions. Bharadwaj's critique focussed on the way in which the west still looks at oriental countries. Our outlook vis-à-vis China is still politically coloured and normative, he declared. He would like for scientists from developing countries to no longer accept unequal access to the international scientific community. The time of the subaltern (an ex colonial outside the power structure) should be over. In short, Bharadwaj would have liked a more politically charged book.

\section{Research deluge}

A major part of the conference dealt with quantifying science and research. There is such a deluge of research papers, even the most hardened TA organisation will find it impossible to read each and every one that is published. A new paper on nanotechnology is published every eight minutes, according to a delegate from the German Fraunhofer Institute. During his presentation alone, another ten were added to the growing library on this subject. In order not to drown in this sea of research papers, bibliometric research is of great importance.

By using software to assess papers, one can get an idea of trends and developments without having to read everything. The Etcetera project is a case in point. It uses bibliometric methods to seek out technologies to be included in the future agenda of the European Union. The project identified I 27 emerging technologies in this way. It then asked a group of experts from the scientific community: which technology is more important than the others? As B. Wepner of Etcetera explained, you end up with a ranking of various technologies: "not a truth, but an assessment." But it is also a blueprint for policy makers of which technology shows the most promise.

\section{Truly international}

Most people at the conference were obviously European, with especially large delegations from Germany and the Nordic countries present. But there were also representatives from further afield. American, Japanese, Chinese, and Israeli TA-professionals were in attendance. A small Australian delegation presented a very interesting case from Tasmania, where they studied companies manufacturing underground mining equipment. 
The researchers down under noticed that a shift from low- to high skilled work is taking place in this sector. Mining equipment becomes increasingly complex and expensive, yet the local work force does not seem to develop equally fast. The result is a mismatch between the Tasmanian labour pool and the skills that are required to manufacture such equipment. This tension is somewhat relieved by cooperation between traditional factory floor workers and specialists with a university degree. The Australians found welders who require input from physicists in order to make the right kind of equipment. Competitors also start talking to each other. Those conversations lead to joint problem solving.

\section{More pizzazz please}

The conference was well attended and lively discussions went on well outside the official sessions. A buffet dinner - with before-dinner drinks courtesy of the Finnish TA-delegation - in the ancient convent of Saint Agnes was one of the highlights of the three day event. If any criticism could be heard in the corridors of the conference, it was that a lot of sessions could be presented with a little more pizzazz. Too many European scientists seem to miss the stage and presentational skills of their American counterparts, who know how to engage an audience by packaging their information in a gripping and even entertaining way. When your message is that important, be passionate about the delivery.

\section{Read More?}

For more information on the conference and to download the book of abstracts:

http://www.pacitaproject.eu/?page_id=1831

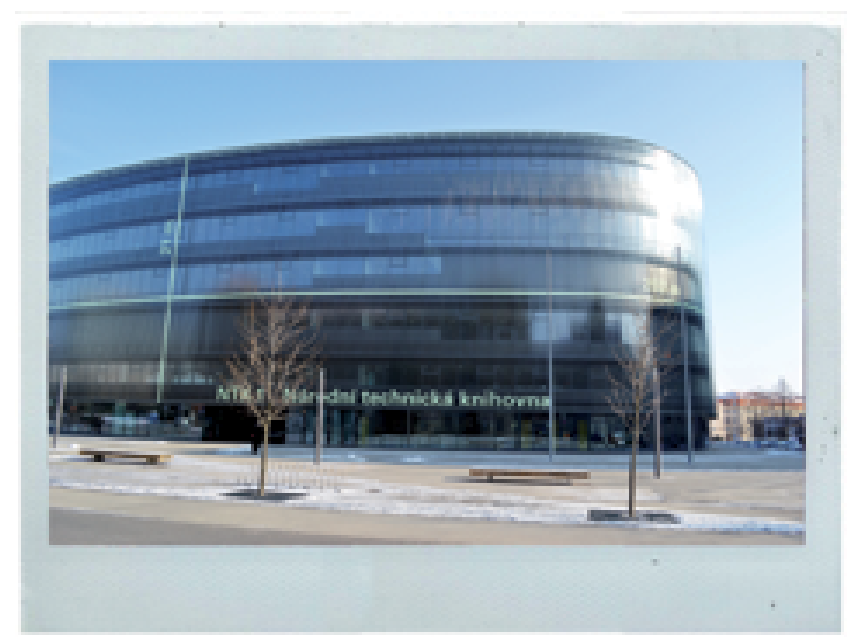

The National Technical Library in Prague

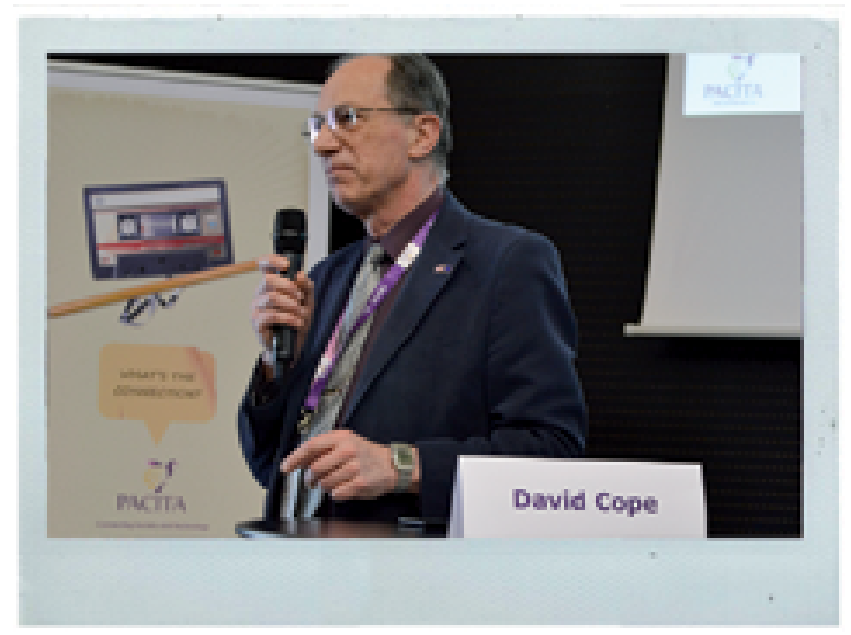

Experienced TA expert David Cope gets th discussion going

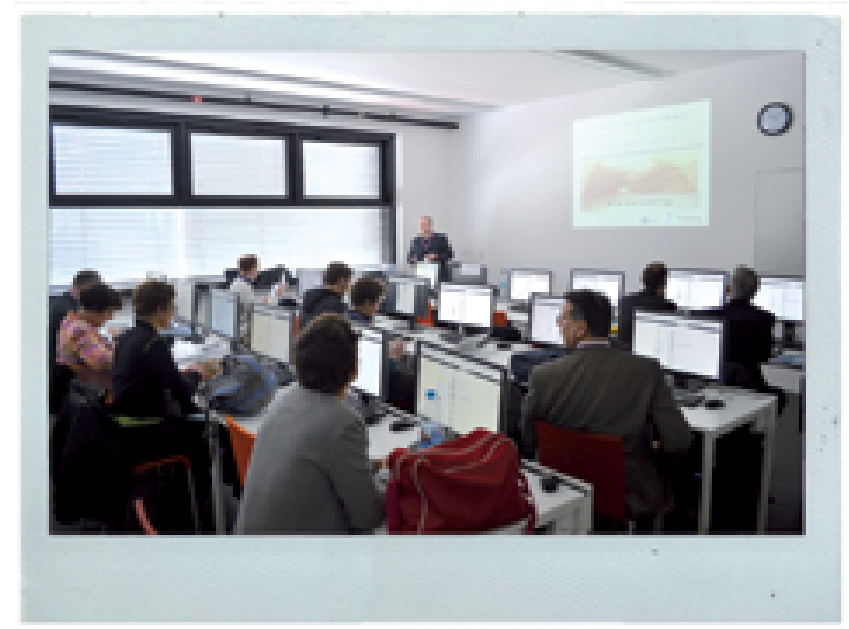


In the new Clinical Trials Directive proposals now under discussion, the EU Commission wants to simplify European authorisation procedures and enhance transparency at the same time. What do membes of the European Parliament think about the proposed amendments?

Text:

Katalin Fodor

Photo:

iStockphoto

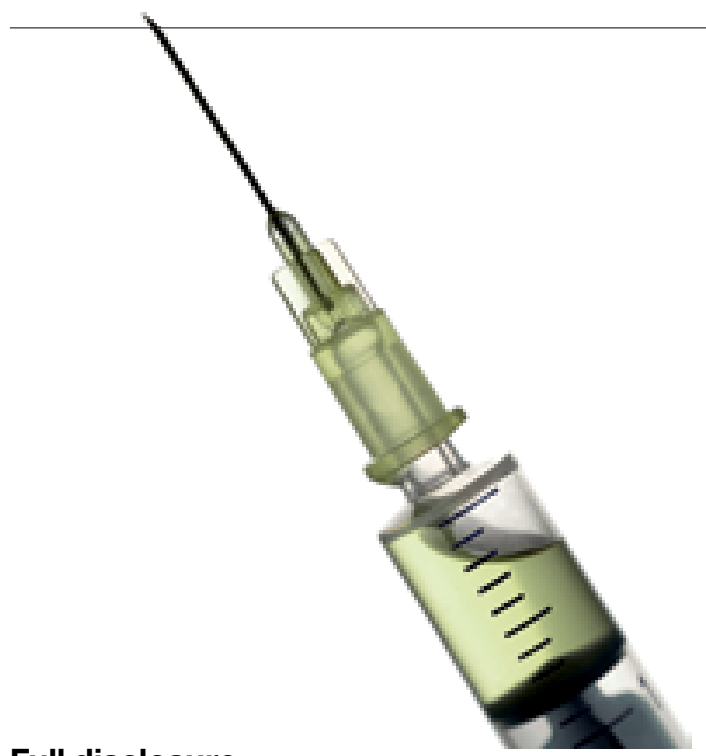

\section{Full disclosure}

"Too many results from clinical trials are misleading, biased or missing. It is time that all pharmaceutical companies and researchers made the full results of studies on new and existing drugs publicly available. I want to see comprehensive results from clinical trials published on a public database - a summary of the results is not enough. For too long unflattering studies have gone undisclosed. It is vital that we know about negative outcomes, otherwise trials can be conducted repeatedly before it becomes public knowledge that they are ineffective or even dangerous."

Glenis Willmott (UK), Group of the Progressive Alliance of Socialists and Democrats in the European Parliament (S\&D). Rapporteur[lead legislator] for the revision of the European rules on clinical trials.

www.gleniswillmott.eu

\section{Preventing brain drain}

"The number of clinical trials over the last few years have surprisingly shown a rather slight increase in the case of Hungary. I welcome the overall objectives of the draft regulation to foster clinical trials and academic research in Europe, especially because it would not only facilitate patients' access to new and more effective therapeutic treatments, but it can also increase my country's potential to keep healthcare professionals at home. Nevertheless, it is important to emphasize that the proposal and any changes do not jeopardize the safety of the subjects and the strict application of the Member States' ethical principles during the assessment of clinical trials."

Erik Bánki (Hungary), Group of the European People's Party (Christian Democrats)

www.bankierik.hu

\section{Amendments are necessary}

"The EU directive from 2001 was a first important step towards more ethical and harmonized clinical trial. I think that amendments are necessary, but it is of fundamental importance not to weaken the role of the ethics committees. Moreover, it is reasonable to determine reporting member states in the process, but the opinions of experts from other concerned countries must equally be included. We must not fall behind the present level of protection for persons who cannot give informed consent. If these amendments are adopted, I support the proposal and definitely consider it a good idea."

Peter Liese (Germany), Group of the European People's Party (Christian Democrats)

www.peterliese.de

\section{Ethics is the core issue}

"In my opinion the Commission uses these figures in order to lower the ethical standards of clinical trials: Clinical trials are of utmost importance both in assessing the effect of new drugs and in monitoring post-marketing authorization. Less bureaucratic procedures are welcome as long as they not lower ethicical standards. The future legislation has to ensure that no clinical trial can start without the prior approval by an independent ethics committee in any Member State concerned. This is for me the core issue."

Alda Sousa (Portugal), Confederal Group of the European United Left - Nordic Green Left www.europarl.europa.eu/meps/en/113487/ALDA_SOUSA. html

\section{Read More?}

EU policy on Medicinal products for human use and the proposal for amendments to the 2001 Clinical Trials Directive: http://ec.europa.eu/health/human-use/clinical-trials/ index_en.htm.

The position of the European Federation of Pharmaceutical Industries and Associations (EFPIA) on the proposal: http:// www.efpia.eu/efpia-position-legal-proposal-regulationeuropean-parliament-and-council-clinical-trials-medicinal 